\title{
Fostering Job Satisfaction: The Role of Communication Quality and Colleague Support in Job Involvement
}

\author{
Ratih Pratiwi \\ Jurusan Manajemen, Fakultas Ekonomi, Universitas Wahid Hasyim Semarang \\ Email: rara@unwahas.ac.id
}

\begin{abstract}
This article aimed to discuss the effect of colleague support, communication quality on work engagement and job satisfaction in 100 human resources sharia hotels in Semarang. To answer hypotheses the data obtained being analysed with structural equation modeling using Partial Least Square (PLS) estimation. The support of colleagues has a significant influence on job satisfaction. Colleague support was found to be insignificant on work involvement. Communication quality has a significant influence on job satisfaction and job involvement. Work involvement does not have a significant effect on job satisfaction. To improve job satisfaction, it is necessary to improve the quality of communication, support from colleagues and work superiors by involving colleagues in various events conducted by the organization. This research does not consider increasing compensation such as awards and awards, as well as other retreats that might increase work engagement on job satisfaction.
\end{abstract}

Keywords: Colleague Support; Communication Quality; Work Engagement; Job Satisfaction

\section{PENDAHULUAN}

Keberhasilan suatu organisasi untuk mencapai tujuannya tergantung pada sikap individu (Dartey, Anlesinya, \& Lamptey, 2019). Elemen lain yang mempengaruhi perilaku karyawan adalah lingkungan dari karyawan itu sendiri, yang dalam hal ini dukungan organisasi yang melingkupinya (García, Miranda, Gallo, \& Roman, 2019).

Antesenden dalam meningkatkan job satisfaction adalah communication quality, dan kerjasama yang baik antar sumber daya manusia (Mundt, \& Zakletskaia, 2019). Lanugo (1982) berpendapat bahwa job involvement berarti efektivitas organisasi dalam jangka panjang. Selain itu, job involvement terkait dengan pengurangan turn over dalam organisasi (Lambert, Qureshi, Frank, Klahm and Smith, 2017). Dalam penelitiannya, Matsuo (2019) menyatakan bahwa perlunya meneliti kemungkinan colleague support sebagai anteseden yang diharapkan mampu meningkatkan job involvement.

Lambert et.al (2010) dalam penelitiannya yang berjudul "Exploring the relationship between colleague support and job burnout among correctional staff", menyatakan bahwa colleague support tidak memiliki hubungan positif terhadap job satisfaction. Sementara penelitian yang dilakukan oleh peneliti yang sama namun dilakukan pada tempat penelitian yang berbeda dan responden yang berbeda pula penelitian Lambert et.al (2016) "Social Support's Relationship To Correctional Staff Job Stress, Job Involvement, Job Satisfaction, And Organizational Commitment" menunjukkan bahwa colleague support berpengaruh positif signifikan terhadap job satisfaction SDM.

Artikel ini bertujuan untuk meneliti pengaruh colleague support, colleague support terhadap job involvement dan job satisfaction pada hotel syariah di Kota Semarang.

\section{METODE PENELITIAN}

Penelitian ini merupakan explanatory research menguji hubungan antar variabel yaitu job involvement, communication quality, colleague support dan job satisfaction. Populasi penelitian merupakan SDM hotel syariah di Kota Semarang dengan jumlah 100 responden dengan kriteria memiliki masa kerja minimal 2 tahun. Teknik sampling yang digunakan adalah teknik sampling insidental, yaitu teknik penentuan sampel berdasarkan kebetulan, siapa saja yang secara kebetulan/ insidental bertemu dengan peneliti dapat digunakan sebagai sampel, bila dipandang orang yang kebetulan ditemui itu cocok sebagai sumber data. Analisis yang digunakan untuk menjawab 
hipotesis adalah permodelan persamaan structural dengan menggunakan pendekatan Partial Least Square (PLS).

\section{HASIL DAN PEMBAHASAN}

Tabel 1. UJI HIPOTESIS

\begin{tabular}{|c|c|c|c|c|c|}
\hline & $\begin{array}{l}\text { Original } \\
\text { Sample } \\
\text { (O) }\end{array}$ & $\begin{array}{l}\text { Sample } \\
\text { Mean } \\
\text { (M) }\end{array}$ & $\begin{array}{l}\text { Standard } \\
\text { Deviation } \\
\text { (STDEV) }\end{array}$ & $\begin{array}{l}\text { T Statistics } \\
(|\mathrm{O} / \mathrm{STDEV}|)\end{array}$ & $\begin{array}{l}\mathbf{P} \\
\text { Values }\end{array}$ \\
\hline $\begin{array}{l}\text { Job involvement _(y1) }-> \\
\text { job satisfaction_(y2) }\end{array}$ & 0.146 & 0.143 & 0.095 & 1.537 & 0.125 \\
\hline $\begin{array}{l}\text { communication } \\
\text { quality_(x2) -> } \quad J o b \\
\text { involvement_(y1) }\end{array}$ & 0.571 & 0.577 & 0.092 & 6.226 & 0.000 \\
\hline $\begin{array}{l}\text { communication } \\
\text { quality_(x2) } \\
\text { satisfaction_(y2) }\end{array} \quad->\quad$ job & 0.278 & 0.296 & 0.093 & 2.984 & 0.003 \\
\hline $\begin{array}{l}\text { colleague support_(x1) -> } \\
\text { Job involvement_(y1) }\end{array}$ & 0.192 & 0.199 & 0.112 & 1.713 & 0.087 \\
\hline $\begin{array}{l}\text { colleague support_(x1) } \quad-> \\
\text { job satisfaction_(y2) }\end{array}$ & 0.504 & 0.495 & 0.109 & 4.638 & 0.000 \\
\hline
\end{tabular}

Tabel di atas menunjukkan bahwa nilai original sample estimate colleague support dan job involvement sebesar 0.192 dengan T-statistik sebesar $1.737<1,99$. Dengan demikian hipotesis H1 dalam penelitian ini yang menyatakan bahwa 'antara colleague support memiliki pengaruh terhadap job involvement ditolak.

Tabel di atas menunjukkan nilai original sample estimate antara colleague support dan job satisfaction sebesar 0.504 yang menunjukkan bahwa colleague support memiliki pengaruh positif terhadap job satisfaction. Nilai T-statistik sebesar $4.638>1,99$ sehingga dinyatakan memiliki hubungan yang signifikan. Dengan demikian hipotesis H2 dalam penelitian ini yang menyatakan bahwa colleague support berpengaruh terhadap job satisfaction diterima.

Tabel di atas menunjukkan bahwa nilai T-statistik hubungan communication quality dan job involvement sebesar $6.226>1,99$ dan nilai original sample estimate sebesar 0,571 yang menunjukkan bahwa arah hubungan antara communication quality dan job involvement adalah positif. Dengan demikian hipotesis H3 dalam penelitian ini yang menyatakan bahwa communication quality berpengaruh terhadap job involvement diterima.

Tabel di atas menunjukkan bahwa hubungan antara communication quality dan job satisfaction adalah signifikan dengan T-statistik sebesar 2,984 >1,99. Nilai original sample estimate adalah positif yaitu sebesar 0,278 yang menunjukkan bahwa arah hubungan antara communication quality dan job satisfaction adalah positif. Dengan demikian hipotesis H4 dalam penelitian ini yang menyatakan bahwa communication quality berpengaruh terhadap job satisfaction diterima.

Nilai original sample estimate job involvement dan job satisfaction sebesar 0,146 yang menunjukkan bahwa arah hubungan antara job involvement dan job satisfaction adalah positif. Tabel di atas menunjukkan bahwa hubungan antara job involvement dan job satisfaction memiliki nilai T-statistik sebesar $1.537<1.99$. Dengan demikian hipotesis H5 dalam penelitian ini yang menyatakan bahwa job involvement berpengaruh terhadap job satisfaction pegawai ditolak.

Berdasarkan nilai original sample estimate maka diperoleh bahwa nilai tertinggi yang mempengaruhi job involvement adalah pada communication quality yaitu sebesar 0,571. Hal tersebut menunjukkan bahwa communication quality mempunyai pengaruh terhadap job involvement lebih tinggi dari pada pengaruh colleague support. Lebih lanjut, dari tiga variabel yang mempengaruhi job satisfaction secara langsung yaitu colleague support, communication quality dan job involvement, yang paling besar pengaruhnya adalah colleague support karena mempunyai nilai original sample estimate tertinggi yaitu sebesar 0,504 dibandingkan dua variabel yang lain. Dengan demikian colleague support merupakan variabel yang paling dominan dalam 
mempengaruhi job satisfaction SDM. Sedangkan variabel yang paling tidak dominan adalah job involvement yaitu dengan original sample estimate terkecil yaitu sebesar 0.146.

\section{KESIMPULAN}

Colleague support memiliki pengaruh signifikan terhadap job satisfaction. Hal ini berarti bahwa semakin seseorang mendapatkan colleague support yang tinggi maka akan semakin tinggi job satisfaction-nya. Dengan adanya colleague support dari berbagai sumber, individu akan merasa yakin bahwa dirinya dicintai dan disayangi, dihargai, bernilai dan menjadi bagian dari jaringan sosial pada lingkungan kerjanya. Colleague support merujuk pada kenyamanan, kepedulian, harga diri atau segala bentuk bantuan yang diterima individu dari orang lain atau kelompok (Bai \& Zhu, 2018). Dalam dunia kerja, seseorang dihadapkan pada situasi kerja yang penuh tuntutan dan tekanan (Li, Pang, \& Xie, 2018). Persepsi SDM terhadap colleague support yang diberikan rekan kerja, kemudahan pengurusan administrasi dan dukungan yang diberikan organisasi akan meningkatkan kepuasan SDM terhadap pekerjaan itu sendiri, semakin puas dengan kondisi lingkungan fisik dan non fisik serta puas akan dukungan pengawasan yang dilakukan atasan.

Colleague support tidak berpengaruh signifikan terhadap job involvement. Hal ini diindikasikan dengan dukungan yang tersedia tidak dianggap sebagai sesuatu yang membantu, individu merasa tidak perlu dibantu atau terlalu khawatir secara emosional sehingga tidak memperhatikan dukungan yang diberikan. Yang kedua adalah ketika dukungan yang diberikan tidak sesuai dengan apa yang dibutuhkan individu. Efek berikutnya adalah sumber dukungan memberikan contoh buruk pada individu seperti melakukan atau menyarankan perilaku tidak sehat sehingga SDM yang diberikan dukungan merasa jengah dan khawatir akan penilaian sosial yang dilakukan rekan kerja lainnya, dinilai sama buruk dengan pemberi dukungan

Communication quality memiliki pengaruh signifikan terhadap job satisfaction. Hal ini berarti bahwa semakin bercommunication quality yang terjalin dalam organisasi maka akan semakin tinggi job satisfaction SDM-nya. Communication quality berpengaruh signifikan terhadap job involvement. Sehingga dapat dirumuskan bahwa semakin baik communication quality SDM maka akan meningkatkan job involvement.

$J o b$ involvement tidak memiliki pengaruh signifikan terhadap job satisfaction. Setiap individu memiliki tingkat job satisfaction berbeda sesuai dengan sistem nilai yang berlaku dalam dirinya. Kepuasan SDM satu dan lainnya berbeda beda. Job involvement yang tinggi belum tentu meningkatkan job satisfaction SDM jika dikaitkan dengan peningkatan pendapatan yang didapatkan. Jika Individu merasa bahwa keterlibatan mereka tidak mendapat reward dan recognisi maka SDM merasa bahwa keterlibatan mereka tidak memberikan apapun, sehingga tidak menambah kepuasan kerja mereka.

\section{IMPLIKASI MANAJERIAL}

Untuk meningkatkan job satisfaction perlu dilakukan peningkatan dalam kualitas berkomunikasi, dukungan dari rekan dan atasan kerja serta melibatkan karyawan dalam berbagai event yang dilakukan organisasi.

\section{KETERBATASAN PENELITIAN}

Berdasarkan hasil penelitian dan pembahasan dapat diketahui kelemahan dari penelitian ini adalah hasil nilai original sample of estimate job involvement yang rendah sehingga tidak mampu meningkatkan job satisfaction. Dan original sample of estimate colleague support yang rendah sehingga tidak mampu memberikan pengaruh yang signifikan terhadap peningkatan job involvement.

\section{AGENDA PENELITIAN MENDATANG}

Penelitian ini belum mempertimbangkan unsur peningkatan kompensasi seperti reward dan recognisi, serta unsur lain yang mungkin dapat meningkatkan pengaruh job involvement terhadap job satisfaction. 


\section{DAFTAR PUSTAKA}

Adams, J.S., Freedman, S., 1976. Equity theory revisited: Comments and annotated bibliography. Advances in Experimental Social Psychology 9, 43-90.

Akila, A., \& Priyadarshini, R. G. (2018). The impact of workplace friendships on organizational commitment and intention to leave. In IOP Conference Series: Materials Science and Engineering (Vol. 390, No. 1, p. 012064). IOP Publishing.

Bai, X., \& Zhu, B. (2018). A review of the research on the sense of organizational support. In 2017 5th International Education, Economics, Social Science, Arts, Sports and Management Engineering Conference (IEESASM 2017). Atlantis Press.

Birkeland, M. S., Nielsen, M. B., Hansen, M. B., Knardahl, S., \& Heir, T. (2017). Like a bridge over troubled water? A longitudinal study of general social support, colleague support, and leader support as recovery factors after a traumatic event. European journal of psychotraumatology, 8(1), 1302692.

Chadi, A., \& Hetschko, C. (2018). The magic of the new: How job changes affect job satisfaction. Journal of Economics \& Management Strategy, 27(1), 23-39.

Choo, Ling Suan. (2017). "Colleague support and role clarity in promoting the work engagement of frontliners in Malaysian hotels." Performance Improvement Quarterly : 29.4 389-405.

Dartey-Baah, K., Anlesinya, A., \& Lamptey, Y. (2019). Leadership behaviors and organizational citizenship behavior: the mediating role of job involvement. International Journal of Business, 24(1), 74-95.

Demir, S. (2018). The relationship between psychological capital and stress, anxiety, burnout, job satisfaction, and job involvement. Eurasian Journal of Educational Research, 18(75), 137154.

Ekstrand, J., Lundqvist, D., Davison, M., D'Hooghe, M., \& Pensgaard, A. M. (2019). Communication quality between the medical team and the head coach/manager is associated with injury burden and player availability in elite football clubs. Br J Sports Med, 53(5), 304-308.

García, G. A., Gonzales-Miranda, D. R., Gallo, O., \& Roman-Calderon, J. P. (2019). Employee involvement and job satisfaction: a tale of the millennial generation. Employee Relations: The International Journal, 41(3), 374-388.

Havens, D. S., Gittell, J. H., \& Vasey, J. (2018). Impact of relational coordination on nurse job satisfaction, work engagement and burnout: Achieving the quadruple aim. Journal of Nursing Administration, 48(3), 132-140.

Hussein, H. K. (2019). Measuring the Impact of Employee Involvement in Decision-Making and Job Performance. Tikrit Journal Of Administrative and Economic Sciences, 2(42), 133.

Judge, T. A., Weiss, H. M., Kammeyer-Mueller, J. D., \& Hulin, C. L. (2017). Job attitudes, job satisfaction, and job affect: A century of continuity and of change. Journal of Applied Psychology, 102(3), 356.

Kanki, Barbara G. (2019) "Communication and crew resource management." Crew resource management. Academic Press. 103-137.

Kanungo, R. N. (1982). Measurement of job and work involvement. Journal of applied psychology, 67(3), 341.

Kaur, R., \& Randhawa, G. (2019). Supervisory Support And Job Involvement: An Exploratory Study Of Government School Teachers In Amritsar. Journal of Organisation \& Human Behaviour, 8(1).

Li, H., Pang, X. L., \& Xie, L. T. (2018). The effects of colleague solidarity and affective commitment on nurses' intent to stay. TMR Integrative Nursing, 2(2), 94-100.

Matsuo, M. (2019). Effect of learning goal orientation on work engagement through job crafting: A moderated mediation approach. Personnel Review, 48(1), 220-233.

Mohanty, A., \& Mohanty, S. (2018). The impact of communication and group dynamics on teamwork effectiveness: The case of service sector organisations. Academy of Strategic Management Journal, 17(4), 1-14.

Mundt, M. P., \& Zakletskaia, L. I. (2019). Professional Communication Networks and Job Satisfaction in Primary Care Clinics. The Annals of Family Medicine, 17(5), 428-435. 
Nguyen, T. T. A., \& Nguyen, L. T. T. (2017). The moderating role of perceived supervisor and colleague support in face culture and creativity relationship (Master's thesis, BI Norwegian Business School).

Omilion-Hodges, L. M., \& Ackerman, C. D. (2018). From the technical know-how to the free flow of ideas: Exploring the effects of leader, peer, and team communication on employee creativity. Communication Quarterly, 66(1), 38-57.

Salessi, S., \& Omar, A. (2019). Job Involvement In Current Research: Update And State Of The Art. Papeles Del Psicologo, 40(1), 46-56.

Shimmin, S. (2019). Understanding the Relationship between Colleague Friendships and Work Engagement with Wellbeing; A Three Wave Study.

Smith, S. A., Patmos, A., \& Pitts, M. J. (2018). Communication and teleworking: A study of communication channel satisfaction, personality, and job satisfaction for teleworking employees. International Journal of Business Communication, 55(1), 44-68.

Smith, M. B., Wallace, J. C., Vandenberg, R. J., \& Mondore, S. (2018). Employee involvement climate, task and citizenship performance, and instability as a moderator. The International Journal of Human Resource Management, 29(4), 615-636.

Lambert, E. G., Altheimer, I., \& Hogan, N. L. (2010). Exploring the relationship between social support and job burnout among correctional staff. Criminal justice and behavior, 37(11), 1217-1236.

Lambert, E. G., Minor, K. I., Wells, J. B., \& Hogan, N. L. 2016. Social Support's Relationship To Correctional Staff Job Stress, Job Involvement, Job Satisfaction, And Organizational Commitment. The Social Science Journal, 53(1): 22-32.

Lambert, E. G., Qureshi, H., Frank, J., Klahm, C., \& Smith, B. (2017). Job Stress, Job Involvement, Job Satisfaction, and Organizational Commitment and Their Associations with Job Burnout Among Indian Police Officers: a Research Note. Journal of Police and Criminal Psychology, 33(2), 85-99. doi:10.1007/s11896-017-9236-y

Lu, H., Zhao, Y., \& While, A. (2019). Job satisfaction among hospital nurses: A literature review. International journal of nursing studies.

Vermeir, P., Downs, C., Degroote, S., Vandijck, D., Tobback, E., Delesie, L., ... \& Vogelaers, D. (2018). Intraorganizational communication and job satisfaction among Flemish hospital nurses: an exploratory multicenter study. Workplace health \& safety, 66(1), 16-23.

Yuen, K. F., Loh, H. S., Zhou, Q., \& Wong, Y. D. (2018). Determinants of job satisfaction and performance of seafarers. Transportation research part A: policy and practice, 110, 1-12.

Yuh, J., \& Choi, S. (2017). Sources of social support, job satisfaction, and quality of life among childcare teachers. The Social Science Journal, 54(4), 450-457. 